\title{
Exploring family needs in neonatal and pediatric intensive care units at King Khaled Hospital- Jeddah
}

\author{
Hend Alnajjar ${ }^{1}$ and Wafaa Elarousy ${ }^{1,2 *}$ \\ ${ }^{1}$ Assistant Professor Pediatric Nursing, College of Nursing Jeddah, King Saud Bin Abdulaziz University for Health Science, KSA \\ ${ }^{2}$ Assistant Professor Pediatric Nursing, Faculty of Nursing, Alexandria University, KSA
}

\begin{abstract}
Family-centered care (FCC) approach acknowledges that the family has the greatest influence over an infant's / child's health and well-being. Assessing the FMs' needs is an important component to apply and improve family-centered care, and it is essential for pediatric nurses in the intensive care units to identify and understand these needs. Meeting the needs of family having neonate or child in intensive care is part of implementing the philosophy of family-centered care.

Aim of the study is to explore nurses', doctors' and parents' perceptions on family needs in pediatric critical care units at King Khaled Hospital in Jeddah.

Methodology: Exploratory and descriptive design was used. doctors, nurses and parents from Pediatric Critical Care Units at King Khalid Hospital, Jeddah participated in the study using non-probability convenient sampling technique. Critical Care Family Needs Inventory (CCFNI) a tool developed by Jane Leske was used for assessing nurses', doctors', and parents' perceptions on family needs. The original English version was translated into Arabic by qualified English to Arabic translator. Validity was tested by Arabic faculty staff members and subjected to a pilot test to test for its validity within this context Reliability of the CCFNI was 0.97 by. Gundo. Ethical consideration was ensured by getting IRB approval and all participants signed the informed consent.
\end{abstract}

\section{Background}

Family need is defined as "a requirement for the family and when this requirement is met, it will relieve or diminish their distress or improves their sense of adequacy or wellbeing. Considering improving family "well-being" is the role of all health care providers, especially nurses [1]. Acute illness requiring hospitalization is considered a stressful situation that can have negative effects on family including emotional distress and altered family roles and functioning. Poor family functioning during the illness experience can in turn negatively affect patient outcomes [2,3]. Additional stresses are added to parents who having infant in neonatal intensive care unit as alteration in parental role, uncertainty of the infants' outcome [4]. One of the challenges that healthcare providers encounter in critical care units is their ability to identify, meet the family needs $[5,6]$. Taking care of family and applying family centered care is of vital importance.

Family-centered care (FCC) approach acknowledges that the family has the greatest influence over an infant's/ child's health and well-being. Health care providers must support, respect, and enhance the competence of the family. These objectives can be achieved by developing a partnership approach [1,7]. Implementing familycentered care results in high-Quality of services for all children. It improves patient, family and health care providers satisfaction in addition to enhance family strengths and more effective use of resources $[8,9]$. Studies examining family roles and levels of involvement within health care found that the strongest evidence for efficacy of FCC is effective use of resources and decrease cost effectiveness [9].

Information Sharing with the family is one of the general principles of implementing FCC [8]. Providing the family with the appropriate, clear, and compassionate information will help them to cope with their distress and support them in making decisions about patients $[10,11]$. Unmet of the parental needs increases the stress and can lead to situation crisis. Many studies have highlighted the importance of identification the needs of family members in order to enable the health care providers in providing adequate emotional and physical support to family members $[2,12,13]$. A qualitative study to identify the perceived needs of Saudi families of patients in Intensive Care indicated that almost all family participants do not aware about the prognosis of their ill relative and this leads to deep feeling of anxiety. They needed information should include diagnostic and treatment procedures, medications used and vital signs.

\section{Problem statement}

Health care professionals should recognize that caring of children extends to the family and its needs in relation to optimizing the care of the child [14]. Family-centered care (FCC) approach acknowledges that the family has the greatest influence over an infant's/child's health and well-being. Family-centered care (FCC) is a partnership approach between the family and health care provider. FCC is considered the standard of pediatric health care that should be used. Although, family centered care is widespread endorsement, it is insufficiently

Correspondence to: Dr. Hend Alnajjar, King Saud Bin Abdulaziz for Health Science, E-mail: najjarha@ngha.med.sa

Key words: nurses, doctors, parents, family needs

Received: August 20, 2017; Accepted: September 18, 2017; Published: September 22,2017 
implemented into clinical Practice. Specific FCC practices should be implemented and evaluated for quality improvement [9]. Furthermore, researches revealed lack of congruence between family needs as perceived by family and the same needs as perceived by health care team $[1,4,14]$. Majority of family needs researches are investigated the needs of family members of hospitalized adult in intensive care unit and very limited researches were done for parent of child in intensive care unit. Assessing the FMs' needs is an important component to apply and improve family-centered care, and it is essential for pediatric nurses and doctors in the pediatric intensive care units to identify and understand these needs. Meeting the needs of family having neonate or child in pediatric intensive care is part of implementing the philosophy of family-centered care.

Aim of the study: is to explore nurses, doctors and parents perceptions on family needs in pediatric critical care units at King Khaled Hospital in Jeddah

\section{The study is intended to answer the following research questions}

1. What are the nurses' perception of family needs in Pediatric Critical Care Units?

2. What are the doctors' perception of family needs in Pediatric Critical Care Units?

3. What are the parents' perception of their needs in Pediatric Critical Care Units?

4. What is the comparison between nurses', doctors' and parents' perception of family needs in Pediatric Critical Care Units?

\section{Materials and methods}

The study was conducted in pediatric critical care units: neonatal intensive care NICU and pediatric intensive care (PICU) at King Khalid Hospital, Jeddah. Fifty-four nurses, twenty-nine doctors and eighteen parents (either fathers or mothers) were recruited for the study with response rate more than $90 \%$. Non-probability convenient sampling was used as all available nurses, doctors and parents from the pediatric critical care units at the time of data collection. All doctors or nurses with less than 6 months of experience working within a critical care unit were excluded. This exclusion is made so as to include the most experienced staff within the pediatric critical care unit. Parents who have a neonate/child admitted to the pediatric critical care unit for less than 12 hours were excluded. This is exclusion is made as parent might be in severe emotional turmoil within the first 12 hours after admission. This research is designed as a quantitative research survey which is exploratory and descriptive in nature as this research explores and describes the family needs from doctors, nurses and parents' perceptions.

Self-reported questionnaire was used. It consists of 2 parts; first part includes the demographic details of respondents. Second part includes needs inventory which consists of forty-five (45) items to elicit participants' responses against the listed items. These statements are related to family needs derived from the Critical Care Family Needs Inventory (CCFNI) a tool developed by Jane Leske. The tool consists of 45 items and five (5) subscales; 14 items for support subscale, 9 items for information subscale, 9 items for proximity or closeness subscales, 7 items for assurance subscale and 6 items for comfort subscale. The responses are noted on a 4-point Likert scale, 1 for not important, 2 for slightly important, 3 for important and 4 for very important [12]. The English version of the tool was used for doctors and nurses and an
Arabic version was used for parents. The original English version was translated by English experts and then given to two Arabic speaking faculty staff members to verify that Arabic content of the tool did not deviate from the original English content. The reliability of the tool was 0.941 using Cronbach's Alpha. The reliability of the tool was 0.97 by Gundo [2].

Validity was tested by Arabic faculty staff members and subjected to a pilot test to test for its validity within this context. Two doctors and four nurses were given the English version of the tool and three parents were given the Arabic version of the tool to ensure that the tool is understandable.

Data were fed to the computer and analyzed using IBM SPSS software package version 20.0. Qualitative data were described using number and percent Quantitative data were described using range (minimum and maximum), mean, standard deviation. Significance of the obtained results was judged at the 5\% level. F-test (ANOVA) was used for normally quantitative variables, to compare between more than two groups.

Permission from the hospital Directors, King Abdullah International Medical Research Center (KAMRC) and IRB approval were obtained. A letter explaining the purpose of the study was attached to the questionnaire. The researchers provided assurance to all the respondents that they are under no obligation to participate in the study and can withdraw at any time. Confidentiality was ensured. Informed consent (written) was obtained from the respondents.

\section{Results}

Tables 1 and 2 illustrate the socio-demographic characteristics of the study participants. Fifty-four nurses participated in the current study, majority of them were females $(94.4 \%)$, about one quarter of them aged less than 29 years while $61.1 \%$ aged between 30 to 49 years. Philippine followed by Malaysia are the common nationality among them (42.6 and 29.6\% respectively). As regards the participants' years of experience in PICU, less than 5 years old was reported by $42.6 \%$ while from 6 to 10 years of experience was reported by $24.1 \&$ of them. In addition, twenty-nine doctors participated in the study, $62.1 \%$ of them were males, $72.4 \%$ of them aged between 30 to 49 years old and $48.3 \%$ of them has less than 5 years' experiences in PICU and majority of them are Saudi. As regards parents' socio-demographic characteristics, two third of the participants were mothers, and about one half of them are aged between 40 to 49 years old and majority of parents are Saudi.

Forty-five family needs inventory was used to assess the nurses', doctors' and parents' perception about family needs in PICU using 4-point Likert scale. The highlights the family needs with high mean scores that perceived by parents, nurses and doctors (Table 3). As regards the highest means for perception of parents about their needs in PICU. They perceived "To know how the patient is being treated medically" and "To know exactly what is being done for the patient" to be their needs priority in PICU with mean of 3.94 and more for the following needs "To talk to the doctor every day", "To have questions answered honestly", "To be assured that the best care possible is being given to the patient", "To feel accepted by the hospital staff", "To feel that the hospital personnel care about the patient" and "To know specific facts concerning the patient's progress". The highest means of perception about family needs for nurses were for "To have questions answered honestly" $(3.65 \pm 0.65)$ and "To be assured that the best care possible is being given to the patient" $(3.65 \pm 0.52)$ followed by To know the expected outcome $(3.63 \pm 0.52)$ To talk to the doctor every day $(3.63 \pm 0.52)$ and To know how the patient is being treated medically 
Table 1. Doctors' and nurses' socio-demographic characteristics.

\begin{tabular}{|c|c|c|c|c|}
\hline & \multicolumn{2}{|c|}{$\begin{array}{c}\text { Doctors } \\
(n=29)\end{array}$} & \multicolumn{2}{|c|}{$\begin{array}{l}\text { Nurse } \\
(n=54)\end{array}$} \\
\hline & No. & $\%$ & No. & $\%$ \\
\hline \multicolumn{5}{|l|}{ Gender } \\
\hline Male & 18 & 62.1 & 3 & 5.6 \\
\hline Female & 11 & 37.9 & 51 & 94.4 \\
\hline \multicolumn{5}{|l|}{ Age } \\
\hline $20-29$ & 7 & 24.1 & 14 & 25.9 \\
\hline $30-39$ & 10 & 34.5 & 18 & 33.3 \\
\hline $40-49$ & 11 & 37.9 & 15 & 27.8 \\
\hline$\geq 50$ & 1 & 3.4 & 7 & 13.0 \\
\hline Min. - Max. & \multicolumn{2}{|c|}{$24.0-52.0$} & \multicolumn{2}{|c|}{$25.0-61.0$} \\
\hline Mean $\pm \mathrm{SD}$ & \multicolumn{2}{|c|}{$36.14 \pm 8.01$} & \multicolumn{2}{|c|}{$37.67 \pm 9.80$} \\
\hline \multicolumn{5}{|l|}{$\begin{array}{c}\text { Nationality } \\
\text { doctor }\end{array}$} \\
\hline Saudi & 19 & 65.5 & 5 & 9.3 \\
\hline Philippine & - & - & 23 & 42.6 \\
\hline Malaysia & - & - & 16 & 29.6 \\
\hline $\begin{array}{c}\text { Others } \\
\text { nationality }\end{array}$ & 10 & 34.5 & 10 & 18.5 \\
\hline \multicolumn{5}{|l|}{$\begin{array}{c}\text { Years of } \\
\text { experience }\end{array}$} \\
\hline $0-5$ years & 14 & 48.3 & 23 & 42.6 \\
\hline $6-10$ years & 6 & 20.7 & 13 & 24.1 \\
\hline $11-15$ years & 7 & 24.1 & 8 & 14.8 \\
\hline 16- 19 years & 1 & 3.4 & 3 & 5.6 \\
\hline 20 and more & 1 & 3.4 & 7 & 13.0 \\
\hline
\end{tabular}

Table 2. Parents' socio-demographic characteristics.

\begin{tabular}{|c|c|c|}
\hline & \multicolumn{2}{|c|}{$\begin{array}{c}\text { Family members } \\
(\mathrm{n}=18)\end{array}$} \\
\hline & No. & $\%$ \\
\hline \multicolumn{3}{|l|}{ Gender } \\
\hline Male & 6 & 33.3 \\
\hline Female & 12 & 66.7 \\
\hline \multicolumn{3}{|l|}{ Age } \\
\hline $20-29$ & 0 & 0.0 \\
\hline $30-39$ & 3 & 16.7 \\
\hline $40-49$ & 8 & 44.4 \\
\hline$\geq 50$ & 7 & 38.9 \\
\hline Min. - Max. & \multicolumn{2}{|c|}{$33.0-55.0$} \\
\hline Mean \pm SD & \multicolumn{2}{|c|}{$47.22 \pm 7.34$} \\
\hline \multicolumn{3}{|l|}{$\begin{array}{c}\text { Nationality family } \\
\text { members }\end{array}$} \\
\hline Saudi & 17 & 94.4 \\
\hline Syrian & 1 & 5.6 \\
\hline \multicolumn{3}{|l|}{$\begin{array}{l}\text { The relationship with the } \\
\text { admitted patient }\end{array}$} \\
\hline Mother & 12 & 67.7 \\
\hline Father & 6 & 33.3 \\
\hline \multicolumn{3}{|l|}{$\begin{array}{l}\text { First time to have family } \\
\text { member in ICU }\end{array}$} \\
\hline Yes & 17 & 94.4 \\
\hline No & 1 & 5.6 \\
\hline
\end{tabular}

$(3.63 \pm 0.52)$. While the highest means for perception of doctors were for "To know the expected outcome" (3.72 \pm 0.45$)$ followed by "To be assured that the best care possible is being given to the patient" (3.69 $\pm 0.47)$ then "To have questions answered honestly" $(3.62 \pm 0.49)$ then "To know why things were done for the patient" $(3.55 \pm 0.63)$ and To have explanations given that are understandable $(3.55 \pm 0.63)$. it was observed that the first three needs were common between the nurses and the doctors.
Table 4 illiterates the lowest means for perception of family needs from parents, nurses and doctors in PICU. It was found that

Comparison between nurses', doctors' and parents' perception of the family needs in PICU is presented in Table 5. It was found that parents' perception about the need to know how the patient is being treated medically and to know exactly what is being done for the patient higher than nurses and doctors and the differences were statistically significant $\left(\mathrm{F}=6.773^{\star} \mathrm{P}=0.002\right.$ and $\mathrm{F}=5.603 \mathrm{P}=0.005$ respectively). In addition, the need to talk to the doctor every day, to feel accepted by the hospital staff, to feel that the hospital personnel care about the patient and to know specific facts concerning the patient's progress were perceived by parents more than nurses and doctors and the differences were statistically significant $(\mathrm{F}=4.069, \mathrm{P}=0.020, \mathrm{~F}=8.620, \mathrm{P}=<0.001$, $\mathrm{F}=7.668, \mathrm{P}=0.001$ and $\mathrm{F}=7.255, \mathrm{P}=0.001)$. Furthermore, the need to visit the PICU at any time was perceived by the parents more than the nurses and doctors and the differences were statistically significant $(\mathrm{F}=$ 7.320, $\mathrm{P}=0.001$ )

Figure 1 illustrates comparison between nurses' doctors', and parents' perception according to family needs subscales in PICU. It was found that the parents' mean score of comfort and information subscales were higher than nurses and doctors $(19.67 \pm 2.68,18.09$ \pm 3.81 and $18.83 \pm 3.49$ respectively for comfort subscale and 31.94 $\pm 1.83,29.85 \pm 4.04$ and $29.69 \pm 4.43$ respectively for information subscale) while doctors' and nurses' mean score for were higher than parents $(43.0 \pm 7.16,41.70 \pm 7.30,40.50 \pm 4.37$ repectively $)$. The differences among all participants were not statistically significant. On the other hands, the parents' mean score of proximity and assurance subscales were higher than nurses and doctors $(30.89 \pm 2.59,26.87 \pm$ 4.42 and $28.41 \pm 4.65$ respectively for proximity subscale and $26.44 \pm$ $1.58,24.11 \pm 3.06$ and $24.83 \pm 3.05$ respectively for assurance subscale) and the differences were statistically significant $(\mathrm{F}=6.255, \mathrm{P}=0.003$ and $\mathrm{F}=4.536, \mathrm{P}=0.013$ respectively)

Table 6 shows the comparison between the total mean score of nurses', doctors', and parents' perception about family needs in PICU. It was found that the total mean score of parents' perception about family needs $(146.11 \pm 8.01)$ was higher compared with the total mean score of nurses' (137.76 \pm 19.08$)$ and doctors' (141.59 \pm 19.18$)$ perception of family needs but the differences were not statistically significant.

\section{Discussion}

The perception of nurses and physicians of family needs compared with the perceptions of parents in pediatric critical care unit is important

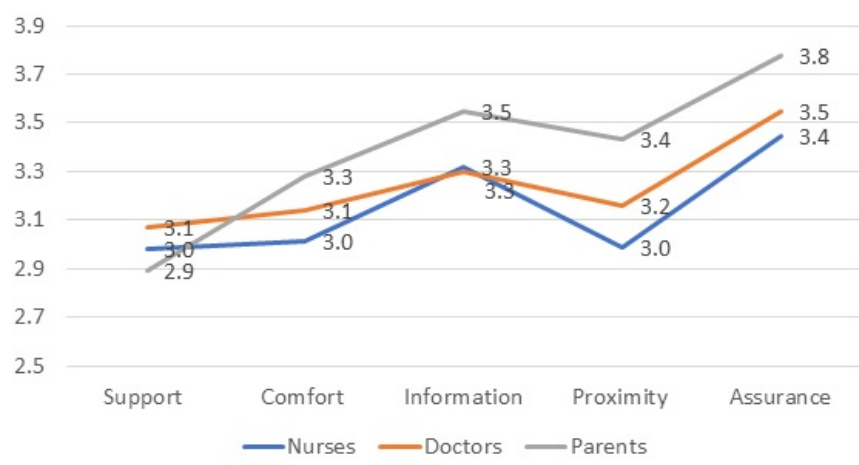

Figure 1. Comparison between nurses', doctors', and parents' perception according to the mean of family needs subscales in PICU $(n=101)$ 
Table 3. The highest mean scores for nurses', doctors' and parents' perception about family needs in PICU.

\begin{tabular}{|c|c|c|c|c|c|}
\hline $\begin{array}{c}\text { Parents } \\
(n=18)\end{array}$ & Mean \pm SD & $\begin{array}{l}\text { Nurse } \\
(\mathrm{n}=54)\end{array}$ & Mean \pm SD & $\begin{array}{c}\text { Doctors } \\
(n=29)\end{array}$ & Mean \pm SD \\
\hline $\begin{array}{l}\text { To know how the patient is being } \\
\text { treated medically. }\end{array}$ & $4.0 \pm 0.0$ & To have questions answered honestly. & $3.65 \pm 0.65$ & To know the expected outcome. & $3.72 \pm 0.45$ \\
\hline $\begin{array}{l}\text { To know exactly what is being done } \\
\text { for the patient. }\end{array}$ & $4.0 \pm 0.0$ & $\begin{array}{l}\text { To be assured that the best care } \\
\text { possible is being given to the patient. }\end{array}$ & $3.65 \pm 0.52$ & $\begin{array}{l}\text { To be assured that the best care possible is } \\
\text { being given to the patient. }\end{array}$ & $3.69 \pm 0.47$ \\
\hline To talk to the doctor every day. & $3.94 \pm 0.24$ & To know the expected outcome. & $3.63 \pm 0.52$ & To have questions answered honestly. & $3.62 \pm 0.49$ \\
\hline To have questions answered honestly. & $3.94 \pm 0.24$ & To talk to the doctor every day. & $3.63 \pm 0.52$ & $\begin{array}{l}\text { To know why things were done for the } \\
\text { patient. }\end{array}$ & $3.55 \pm 0.63$ \\
\hline $\begin{array}{l}\text { To be assured that the best care } \\
\text { possible is being given to the patient }\end{array}$ & $3.94 \pm 0.24$ & $\begin{array}{l}\text { To know how the patient is being } \\
\text { treated medically }\end{array}$ & $3.63 \pm 0.52$ & $\begin{array}{l}\text { To have explanations given that are } \\
\text { understandable }\end{array}$ & $3.55 \pm 0.63$ \\
\hline To feel accepted by the hospital staff & $3.94 \pm 0.24$ & $\begin{array}{l}\text { To know why things were done for } \\
\text { the patient }\end{array}$ & $3.61 \pm 0.63$ & $\begin{array}{l}\text { To feel that the hospital personnel care } \\
\text { about the patient }\end{array}$ & $3.52 \pm 0.78$ \\
\hline $\begin{array}{l}\text { To feel that the hospital personnel } \\
\text { care about the patient }\end{array}$ & $3.94 \pm 0.24$ & $\begin{array}{l}\text { To have explanations of the } \\
\text { environment before going into the } \\
\text { critical care unit for the first time }\end{array}$ & $3.52 \pm 0.61$ & $\begin{array}{l}\text { To know specific facts concerning the } \\
\text { patient's progress }\end{array}$ & $3.52 \pm 0.74$ \\
\hline $\begin{array}{l}\text { To know specific facts concerning the } \\
\text { patient's progress }\end{array}$ & $3.94 \pm 0.24$ & $\begin{array}{l}\text { To know exactly what is being done } \\
\text { for the patient }\end{array}$ & $3.48 \pm 0.61$ & To talk to the doctor every day & $3.48 \pm 0.69$ \\
\hline
\end{tabular}

Table 4. The lowest mean scores for nurses', doctors' and parents' perception about family needs in PICU.

\begin{tabular}{|c|c|c|c|c|c|}
\hline Parents $(n=18)$ & Mean \pm SD & Doctors $(n=29)$ & Mean \pm SD & Nurse $(n=54)$ & Mean \pm SD \\
\hline $\begin{array}{l}\text { To be told about someone to help } \\
\text { with family problems. }\end{array}$ & $2.22 \pm 0.94$ & To be alone at any time. & $2.31 \pm 0.93$ & To talk to the same nurse every day. & $2.31 \pm 1.0$ \\
\hline To feel it is alright to cry. & $2.28 \pm 0.89$ & $\begin{array}{l}\text { To be told about someone to help with } \\
\text { family problems. }\end{array}$ & $2.65 \pm 0.80$ & To visit at any time. & $2.69 \pm 1.14$ \\
\hline To be alone at any time. & $2.28 \pm 0.83$ & To talk to the same nurse every day. & $2.31 \pm 0.97$ & $\begin{array}{l}\text { To have another person with you } \\
\text { when visiting the critical care unit. }\end{array}$ & $2.69 \pm 1.04$ \\
\hline $\begin{array}{l}\text { To have someone to help with } \\
\text { financial problems. }\end{array}$ & $2.44 \pm 0.78$ & $\begin{array}{l}\text { To have another person with you when } \\
\text { visiting the critical care unit. }\end{array}$ & $2.76 \pm 0.95$ & $\begin{array}{l}\text { To have a place to be alone while in } \\
\text { the hospital. }\end{array}$ & $2.79 \pm 0.98$ \\
\hline
\end{tabular}

Table 5. Comparison between nurses', doctors' and parents' perception of the family needs in PICU.

\begin{tabular}{|c|c|c|c|c|c|}
\hline \multirow[t]{2}{*}{ Family needs } & $\begin{array}{c}\text { Parents } \\
(n=18)\end{array}$ & $\begin{array}{c}\text { Doctors } \\
(n=29)\end{array}$ & $\begin{array}{l}\text { Nurse } \\
(n=54)\end{array}$ & \multirow[t]{2}{*}{$\mathbf{F}$} & \multirow[t]{2}{*}{$\mathbf{p}$} \\
\hline & Mean \pm SD. & Mean \pm SD. & Mean \pm SD. & & \\
\hline To know how the patient is being treated medically & $4.0 \pm 0.0$ & $3.41 \pm 0.68$ & $3.63 \pm 0.52$ & $6.773^{*}$ & $0.002^{*}$ \\
\hline To know exactly what is being done for the patient & $4.0 \pm 0.0$ & $3.48 \pm 0.74$ & $3.48 \pm 0.61$ & $5.603^{*}$ & $0.005^{*}$ \\
\hline To talk to the doctor every day & $3.94 \pm 0.24$ & $3.48 \pm 0.69$ & $3.63 \pm 0.52$ & $4.069^{*}$ & $0.020^{*}$ \\
\hline To feel accepted by the hospital staff & $3.94 \pm 0.24$ & $3.38 \pm 0.56$ & $3.28 \pm 0.68$ & $8.620^{*}$ & $<0.001^{*}$ \\
\hline To know specific facts concerning the patient's progress & $3.94 \pm 0.24$ & $3.52 \pm 0.74$ & $3.33 \pm 0.58$ & $7.255^{*}$ & $0.001^{*}$ \\
\hline To be called at home about changes in the patient's condition & $3.89 \pm 0.32$ & $3.31 \pm 0.85$ & $3.15 \pm 0.81$ & $6.400^{*}$ & $0.002^{*}$ \\
\hline To receive information about the patient at least once a day & $3.83 \pm 0.51$ & $3.38 \pm 0.73$ & $3.26 \pm 0.59$ & $5.798^{*}$ & $0.004^{*}$ \\
\hline To see the patient frequently & $3.83 \pm 0.51$ & $3.31 \pm 0.89$ & $3.13 \pm 0.80$ & $5.388^{*}$ & $0.006^{*}$ \\
\hline To help with the patient's physical care & $3.72 \pm 0.57$ & $3.03 \pm 0.78$ & $3.15 \pm 0.81$ & $4.966^{*}$ & $0.009^{*}$ \\
\hline To visit at any time & $3.72 \pm 0.67$ & $2.69 \pm 1.14$ & $2.78 \pm 0.98$ & $7.320^{*}$ & $0.001^{*}$ \\
\hline To have comfortable furniture in the waiting room & $2.67 \pm 0.77$ & $3.21 \pm 0.68$ & $2.85 \pm 0.81$ & $3.228^{*}$ & $0.044^{*}$ \\
\hline To have someone to help with financial problems & $2.44 \pm 0.78$ & $3.24 \pm 0.69$ & $2.91 \pm 0.85$ & $5.565^{*}$ & $0.005^{*}$ \\
\hline To feel it is alright to cry & $2.28 \pm 0.89$ & $3.24 \pm 0.83$ & $3.02 \pm 0.92$ & $6.824^{*}$ & $0.002^{*}$ \\
\hline To be alone at any time & $2.28 \pm 0.83$ & $2.83 \pm 0.85$ & $2.24 \pm 0.93$ & $4.365^{*}$ & $0.015^{*}$ \\
\hline To be told about someone to help with family problems & $2.22 \pm 0.94$ & $3.10 \pm 0.82$ & $2.65 \pm 0.80$ & $6.455^{*}$ & $0.002^{*}$ \\
\hline
\end{tabular}

F,p: $\mathrm{F}$ and $\mathrm{p}$ values for ANOVA test

$*$ : Statistically significant at $\mathrm{p} \leq 0.05$

Table 6: Comparison between the total mean score of nurses', doctors', and parents' perception about family needs in PICU $(n=101)$.

\begin{tabular}{|c|c|c|c|c|c|}
\hline & $\begin{array}{c}\text { Nurses } \\
(\mathbf{n = 5 4 )}\end{array}$ & $\begin{array}{c}\text { Doctors } \\
(\mathbf{n = 2 9})\end{array}$ & $\begin{array}{c}\text { Parents } \\
(\mathbf{n = 1 8})\end{array}$ & Test of sig. & $\mathbf{p}$ \\
\hline Total score & & & & & \\
\hline Min. - Max. & $88.0-175.0$ & $109.0-176.0$ & $133.0-158.0$ & $\mathrm{~F}=$ & \multirow{2}{*}{0.226} \\
\cline { 1 - 3 } Mean \pm SD. & $\begin{array}{c}137.76 \pm \\
19.08\end{array}$ & $\begin{array}{c}141.59 \pm \\
19.18\end{array}$ & $146.11 \pm 8.01$ & 1.512 & \\
\hline
\end{tabular}

F: F value for ANOVA test

*: Statistically significant at $\mathrm{p} \leq 0.05$ to optimize family support. A baseline account of the perceptions from the health care providers can lead to suitable recommendations that may prepare the family members for required caregiving demands, appropriate decision making and to reduce the impact of the crises of critical disease [15]. Our study shows that highest means of perception about family needs for nurses recruited in our study were for honest dialogue followed by assurance of best possible care and knowledge of expected outcome. The perception for the more viable family needs e.g. to speak to the treating physician and have a knowledge of the 
medical treatment plan was also high. With regards to the patient, the two most important concerns rated was "To know how the patient is being treated medically" and "To know exactly what is being done for the patient" (Table 3). Although, Panter-Brick [16] reported in an earlier study involving Saudi parents for ill children that "awareness of medical facts" did not substantially account for emotional comfort in Saudi parents. According to Ali [17] the knowledge of Saudi mothers to manage medical emergencies was reported to be inadequate. However, the results of our study (Table 3) indicate that the concern to access medical facts by parents with regards to treatment of their children outweighs all other issues. This is a significant finding which highlights that the awareness surrounding medical procedures has raised considerably in Saudi parents probably due to extensive public medical services e.g. telemedicine and awareness generated in KSA [18]. These family need perceptions with highest mean score are not unusual since Saudi mothers are well known for their love, tenderness and caregiving attitude strengthened by their firm religious background and values $[19,20]$.

Figure1 shows that when perception according to family needs subscales in PICU were compared among nurses' doctors', and parents', the two core family needs comprising of "information" and "assurance" were perceived to be the most important in Saudi parents. The family need for information and updates regarding medical treatment regarding children is considerably valued which instills confidence in medical care at all levels. Hence this can build focus on the treating pediatricians, assuring good practice thus reducing risk of medical errors, disclosure of which is a very difficult and debatable aspect [21].

Saudi parents have strong emotional bonds with their children, governed by stringent cultural and religious values and young Saudi children (under the age of 5 years) spends more time with their parents [22]. The need to protect and provide utmost care is the reason behind the highly rated Saudi parent perceptions shown in Table 5.

The most important family need (FN) from the perspective of nurses rises out to be "To have questions answered honestly" (3.65 \pm 0.65). This is in line with a recent study by Ellis et.al [23], who observed that false hope is fostered with unrealistic expectations of both the clinicians and the families; it was stated by the nurses that discrepancies in information can both confuse and disturb the family members and impact family resilience in a negative manner. Table 5 shows that the highest mean of perception of the FN about honest response in families $(3.94 \pm 0.24)$ exceed than the doctors $(3.62 \pm 0.49)$ and nurses $(3.65$ $\pm 0.65)$ perception. As per nursing viewpoint coping adequately with this family need will also minimize their stress in crises debriefing [24].

While measuring the means of FN perceptions of the doctors, the highest mean was for the appropriate knowledge of the expected outcome. By ensuring this family need, the doctor can proceed with the treatment while confiding in the families about the goal of treatment with outcome measures. Qualitative studies advocate that a timely conversation to discuss the treatment options and relevant consequences can help the families in making difficult decisions to ensure appropriate care [25]. Table 4 shows that the doctors value the family need to ensure the families that the best possible medical care is provided to the critically ill. Our study shows that the need to assure the family that the patient has been treated with the best possible care is also perceived to be very important by nurses $(3.65 \pm 0.52)$. The participation of clinical nurses at family conferences in PICU is shown to be very effective [26] to comply with this FN.
Whilst recording the family perception of family needs, a unanimous and strong perception of family need weighs heavily on two aspects of their knowledge about how the patient is being treated medically and what is the exact procedure to which the patient is subjected. It has been reported in other studies as well that most parents consider it a responsibility to understand the treatment type received by the child and also to keep tabs on prognosis and subsequent improvement in condition of their child by inquiring the staff [27]. Michelson et. Al [28] reported that the parents with children admitted in PICU are more concerned for seeking explanations and there is a need for relaying information by health care team members in understandable manner. The FN for availability of the health care staff throughout the hospitalized period of the child in a pediatric critical care unit is required to optimize treatment outcome [29].

Based on experiences with pediatric cardiac surgery cases, Simeone et al. [30] have speculated that parent education prior to surgery on what to expect during and after surgery of their child can contribute to reduction in anxiety and enhancement in parent's satisfaction and required knowledge. The families also emphasize on their need to talk to the doctor on daily basis. Several studies uphold this family need and have shown favorable outcomes of ensuring it in critical care settings. October et. al/ [31] advocate that parent satisfaction is largely associated with patient centered communication patterns during family conferences with the physician. In our study setting, most of the parents were not efficient in understanding English whereas the physician and nurses did not have Arabic as their primary language. Studies have shown that language barrier can lead to suboptimal communication [32]. which can be minimized by increasing awareness and efficient use of interpreter.

In a study similar to ours, Selena [33] reported that although the care providers and family members share some perspectives on the involvement of the families in the ICU, there are some discordant perspectives as well which may implicate collaborative decision making.

All three groups in our study emphasized on the FN "To have explanations of the environment before going into the critical care unit for the first time". Using cognitive map improves the ability of the physician to effectively communicate with the families in the critical care units with the "ask-tell-ask" model [34]. The comparison between the total mean score of nurses', doctors', and parents' perception about family needs in PICU is not statistically significant ( $p=0.226 \geq 0.05)$, shown in Table 7. Therefore, findings of our study show the highest priority need as perceived by all groups of participants are similar. The family perception of the family needs is also in line with the priorities of FN by the health care providers. The Assurance subscale (Table 6) shows that there is a significant difference in perceptions of participants $(\mathrm{p}=0.13 \leq 0.05)$, which is perceived lowest in nurses $(24.11 \pm 3.06)$ and highest in parents $(26.44 \pm 1.58)$. The difference between perceptions of the participants (shown in Table 6) on the proximity subscale is highly significant $(\mathrm{p}=0.003 \leq 0.05)$, which is lowest in nurses $(26.87 \pm 4.42)$ and highest in parents $(30.89 \pm 2.59)$.

The findings of our studies should be considered knowing that the Saudi parents belong to the homeland of Islam. Islam originated in the very region delivered by the Holy prophet Mohammed (P.B.U.H). It is also the center of holy pilgrimage for Muslims globally. The cultural and religious influences on the Muslim families form strong family ties and the roles of family as a unit [35]. Hence, in such families, where members have strong social and emotional ties, a critical illness of a child results in participation of all family members with raised expectations to play effective roles in the caring process [35-36]. It is 
not unusual in Saudi Arabia for families to travel long distances and pay visit to the admitted patient. A major restraint of this traditional practice is noted in most ICUs of hospitals in Saudi Arabia, with restricted visitation policies.

The parent perception of family needs (proximity sub-scale) is significantly higher than nurses and physicians as shown in Figure 1. Comparison between nurses', doctors' and parents' perception of the family needs in PICU shows that the highest difference in perception exists for the family need "to visit the patient any time" $(p=0.001)$ followed by "to see patient frequently" $(\mathrm{p}=0.006)$. This family need is prioritized by the parents and, may result in improvements in patient care, in line with recent findings on the subject supporting flexible visiting hours for the patient [37]. The differences in family need perceptions among the three groups of study participants also existed in "helping with the patient care" $(p=0.009)$, shown in Table 5. The value of this family need of Saudi parents should be valued more since the role of the family members care providers is widely accepted [38] and requires continuous support.

\section{Conclusion and recommendation}

Our study shows the differences between family needs from health care providers and parents perceptions. There is a homogenous approach in some needs and differences in other needs. The study recommended that all health care providers either nurses of doctors should be aware about the priorities of family needs from the family perspectives to be able to meet their needs and to improve the implementation of family-centered care approach.

\section{Acknowledgement}

We would like to express our appreciation to the King Abdullah International Medical Research Center (KAMRC) for financial support. Also, we would like to extend our appreciation to all nurses, doctors and parents who participated in the study.

\section{References}

1. Mundy CA (2010) Assessment of family needs in neonatal intensive care units. Am J Crit Care 19: 156-163. [Crossref]

2. Gundo R (2014) Comparison of Nurses' and Families' Perception of Family Needs in Critical Care Unit at Referral Hospitals in Malawi. Open Journal of Nursing 4: 312 320 .

3. Van Horn ER, Kautz D (2007) Promotion of family integrity in the acute care setting: a review of the literature. Dimens Crit Care Nurs 26: 101-107. [Crossref]

4. Ward K (2001) Perceived needs of parents of critically ill infants in a neonatal intensive care unit (NICU) Pediatr Nurs 27: 281-286. [Crossref]

5. Al-Mutair A, Plummer V, Clerehan R, O'Brien A (2013) Needs and experiences of intensive care patients' families: a Saudi qualitative study. British Association of Critical Care Nurses 19: 135-144.

6. Al-Mutair A, Plummer V, O’Brien A, Clerehan R (2013) Family needs and involvement in the intensive care unit: a literature review. J Clin Nurs 22: 1805-1817. [Crossref]

7. Wong D, Hockenberry M (2011) Nursing Care of Infants and Children.

8. Goode T, Haywood S, Wells C (2009) Family-Centered, culturally and linguistically competent care: Essential components of medical home. Pediatr Ann 38: 505-512. [Crossref]

9. Kuo DZ, Houtrow AJ, Arango P, Kuhlthau KA, Simmons JM, et al. (2012) Familycentered care: current applications and future directions in pediatric health care. Matern Child Health J 16: 297-305. [Crossref]

10. Azoulay E, Pochard F, Chevret S (2002) Impact of a Family Information Leaflet on Effectiveness of Information Provided to Family Members of Intensive Care Unit Patients: A Multicenter, Prospective, Randomized, Controlled Trial Am J Respir Crit Care Med 165: 438-442. [Crossref]
11. Siddiqui S, Sheikh F, Kamal R (2011) "What families want - an assessment of family expectations in the ICU”. Int Arch Med 4: 21-28. [Crossref]

12. Dharmalingam TK, Kamaluddin MR, Hassan SK (2016) Factorial Validation and Psychometric Properties Establishment of Malay Version Critical Care Family Need Inventory. Int Med J Malaysia 15: 51-60.

13. Buyukcoban S (2015) Adaptation of the Critical Care Family Need Inventory to the Turkish population and its psychometric properties. Peer $j$ [Crossref]

14. Bowden V, Greenberg C (2010) Children and their families the continuum of care. 2nd ed, Philadelphia: Wolters Kluwer, Lippincott Williams \& Wilkins.

15. Davidson JE, Aslakson RA, Long AC, Puntillo KA, Kross EK, et al. (2017) Guidelines for Family-Centered Care in the Neonatal, Pediatric, and Adult ICU. Critical Care Medicine 45: 103-128. [Crossref]

16. Panter-Brick,Catherine. (1991) Parental responses to consanguinity and genetic disease in Saudi Arabia. Soc Sci Med. 33 (11) : 1295-1302

17. Ali SN (2016) Awareness of emergency management of dental trauma among mothers in Al-Qassim, Saudi Arabia. J Stomat Occ Med 8: 25-29.

18. Bahanshal S, Coughlin S, Liu B (2017) For You and Your Baby (4YYB): Adapting the Centers for Disease Control and Prevention's Text4Baby Program for Saudi Arabia. JMIR Res Protoc 6: e23. [Crossref]

19. Sijeeni AS (2016) Understanding the experiences of mothers caring for children with down syndrome in Saudi Arabia.

20. Qutub S (2016) A case study exploring the ethnic identity of sojourners: Saudi mothers and children's perspectives.

21. Kolaitis IN, Schinasi DA, Ross LF (2016) Should Medical Errors Be Disclosed to Pediatric Patients? Pediatricians' Attitudes Toward Error Disclosure. Acad Pediatr 16: 482-488. [Crossref]

22. Alshehri A (2016) Social and Behavioral Determinants of Early Childhood Caries in the Aseer Region of Saudi Arabia. Gavin J Dent Sci 2016: 44-49.

23. Ellis L, Gergen J, Wohlgemuth L, Nolan MT, Aslakson R (2016) Empowering the "cheerers": role of surgical intensive care unit nurses in enhancing family resilience. Am J Crit Care 25: 39-45. [Crossref]

24. Becker CA, Wright G, Schmit K (2017) Perceptions of dying well and distressing death by acute care nurses. Appl Nurs Res 33: 149-154. [Crossref]

25. Pitcher D, Fritz Z, Wang M, Spiller JA (2017) Emergency care and resuscitation plans. $B M J$ 356: j876. [Crossref]

26. Watson AC, October TW (2016) Clinical nurse participation at family conferences in the pediatric intensive care unit. Am J Crit Care 25: 489-97. [Crossref]

27. Foster K, Young A, Mitchell R, Van C, Curtis K (2017) Experiences and needs of parents of critically injured children during the acute hospital phase: A qualitative investigation. Injury 48: 114-120. [Crossref]

28. Michelson K, Clayman ML, Ryan C, Emanuel L, Frader J (2016) Communication During Pediatric Intensive Care Unit Family Conferences: A Pilot Study of Content, Communication, and Parent Perceptions. Health Commun 11: 1-8. [Crossref]

29. Foster M, Whitehead L, Maybee P (2016) The parents', hospitalized child's, and health care providers' perceptions and experiences of family-centered care within a pediatric critical care setting: A synthesis of quantitative research. J Fam Nurs 22: 6-73. [Crossref]

30. Simeone S, Pucciarelli G, Perrone M, Rea T, Gargiulo G (2017) Comparative Analysis: Implementation of a Pre-operative Educational Intervention to Decrease Anxiety Among Parents of Children With Congenital Heart Disease. J Pediatr Nurs 35: 144148. [Crossref]

31. October TW, Hinds PS, Wang J, Dizon ZB, Cheng YI, Roter DL (2016) Parent Satisfaction with Communication Is Associated With Physician's Patient-Centered Communication Patterns During Family Conferences. Pediatr Crit Care Med 17: 490497. [Crossref]

32. Zurca AD, Fisher KR, Flor RJ, Gonzalez-Marques CD, Wang J, et al. (2017) Communication With Limited English-Proficient Families in the PICU. Hospital Pediatrics 7: 9-15.

33. Selena S Au, Amanda Roze des Ordons, Andrea Soo, Simon Guienguere, Henry T Stelfox. (2017) Family participation in intensive care unit rounds: Comparing family and provider perspectives. journal of critical care. 38: 132-136. 
34. McFarlin J, Tulsky JA, Back AL, Arnold RM (2017) A Talking Map for Family Meetings in the Intensive Care Unit. JCOM

35. Wehbe-Alamah, H. (2008) Bridging generic and professional care practices for Muslim patients through use of Leininger's Culture Care Modes. Contemp Nurse 28 (1-2):83-97.

36. Guan X, Li X. A Cross-Cultural Examination of Family Communication Patterns, Parent-Child Closeness, and Conflict Styles in the United States, China, and Saudi Arabia. J Fam Commun 2017 Jul 3;17(3):223-37.
37. Mitchell ML, Aitken LM (2017) Flexible visiting positively impacted on patients, families and staff in an Australian Intensive Care Unit: A before-after mixed method study. Aust Crit Care 30: 91-97. [Crossref]

38. Tomoaia-Cotisel A, Farrell TW, Solberg LI, Berry CA, Calman NS, Cronholm PF, Donahue KE, Driscoll DL, Hauser D, McAllister JW, Mehta SN. (2016) Implementation of Care Management: An Analysis of Recent AHRQ Research. Medical care research and review.

Copyright: (C2017 Alnajjar H. This is an open-access article distributed under the terms of the Creative Commons Attribution License, which permits unrestricted use, distribution, and reproduction in any medium, provided the original author and source are credited. 